\title{
Dijital Karşılaşmalar: Taktiksel Sanat Müdahalelerinin Politikası
}

\section{Digital Encounters: The Policy of Tactical Art Interventions}

Kevser Akçıl, Resim Bölümü, Sakarya Üniversitesi

\begin{abstract}
Özet
İnternetin sağladığı ağ ortamı, yeni etkileşim ve iletişim biçimlerinin oluşmasına neden olmuştur. Katılımcıların artmasıyla gelişen ağ ortamı sayesinde sanatçılar bilgisayar teknolojileri ile çalışarak hem sanal ortamda sanatsal ifade biçimlerini deneyimlemiş; hem de güncel ekonomik, sosyal ve politik konuları taktiksel açıdan gündeme getirip, mevcut kapitalist sistemlere meydan okuyan, geçici müdahalelerde bulunmuşlardır. Dijital medya aracilığıyla gerçekleştirilen taktiksel yöntemleri incelemeden önce makalede taktiksel sanat hareketlerinin düşünsel ve tarihsel zeminini oluşturan 1960'lardaki gündelik hayatın içinde gerçekleşen, anlık etki yaratan avangart hareketler incelenmiştir. 1990'larda tanımlanan taktik, strateji, taktiksel medya ve taktiksel eğlence kavramları açıklanmış ve taktiksel sanat müdahale yöntemleri Christian Scholl'ün sanatsal müdahale, Nicholas Bourrioud ve Claire Bishop'ın ilisskisel estetik metinleri, Hardt ve Negri'nin çokluk, Antonio Gramsci'nin kültürel hegemonya teorileriyle ilişsilendirilmiștir. Son bölümde ise, Paolo Cirio'nun Loophole for All çalışmasının taktiksel yapısı incelenerek dijital ortamda sosyal iliş̧ilerle gerçekleşen ilişkisel estetik ve katılımcı çalışmalara benzer şekilde ilişkilerin, çatışma ya da uzlaşma sağlanarak dijital ağ üzerinde ve ağ sayesinde karşılaşmalar kurulabileceği öne sürülmüștür. Ancak aktivist, sanatsal, anlık hareketler sokakta ve hayatta fiilen toplumsal dönüşüme yönelik ve müdahaleye açık gerçekleștirilirken; taktiksel medya ile karşılaşmaların internet ve teknoloji sayesinde sanal ortamda toplumsal dönüşümü hedefleyen salt pragmatist tavirla ya da salt sanatsal ve sosyal söylemlerin ötesinde bir özerklik üretimi potansiyeli taşıdığı ifade edilmiştir.
\end{abstract}

Anahtar Sözcükler: Taktiksel, sanat, medya, avangard, aktivizm, ă̆, dijital.

Akademik disipin(ler)/alan(lar): Sanat, iletişim, medya, siyaset.

\begin{abstract}
The network environment provided by the Internet has led to the formation of new forms of interaction and communication. Thanks to the network environment that has developed with the increase of the participants, the artists have experienced artistic expressions both in the virtual environment by working with computer technologies; they also made temporary interventions that challenged existing capitalist systems by bringing up the current economic, social and political issues tactically. Before examining the tactical methods carried out through digital media, the article examines the avantgarde movements that formed the intellectual and historical basis of the tactical art movements in the daily life of the 1960s and created an instant effect. The concepts of tactic, strategy, tactical media and tactical entertainment described in the 1990s were explained and tactical art intervention methods have been associated with Christian Scholl's artistic intervention text, Nicholas Bourrioud and Claire Bishop's relational aesthetics texts, Hardt and Negri's theory of multitude, Antonio Gramsci's cultural hegemony theory. In the last section, by examining the tactical structure of Paolo Cirio's Loophole for All artwork, it has been suggested that relations, similar to the relational aesthetics and participatory studies carried out with social relations in the digital environment, can be established on the digital network and through the network by providing conflict or compromise. However, while activist, artistic, instant movements are actualized in the street and in life towards social transformation and open to intervention; It has been stated that encounters with tactical media can occur in the virtual space thanks to the internet and technology, and they have the potential to produce autonomy beyond purely pragmatist attitude targeting social transformation or purely artistic and social discourses.
\end{abstract}

Keywords: Tactical, art, media, avantgarde, activism, network, digital.

Academical disciplines/fields: Art, communication, media, politics.

- Sorumlu Yazar: Kevser Akçıl, Resim Bölümü, Sanat, Tasarım ve Mimarlık Fakültesi, Sakarya Üniversitesi.

- $\quad$ Adres: Hızırtepe Mah., Fatih Cad., No:123, K:2, D:4, Adapazarı, Sakarya

- $\quad$ e-posta: kevserakcil@sakarya.edu.tr

- ORCID: 0000-0001-7967-0397

- Çevrimiçi yayın tarihi: 25.10 .2021

- doi: $10.17484 /$ yedi.953179 


\section{Giriş}

Genelde savaș terminolojisi ile ilișkili olan taktik ve strateji kelimeleri, belirlenmiş hedeflere göre istenen bir sonuca ulaşma amacıyla planlanan bir dizi eylem türüdür. Medya teorisyeni Michel De Certeau, baskın otoritelerin karşısında bir mücadele biçimi olarak geçici, oyunsu, hilekâr, öykünme şeklinde neşeli ve şairane bulguları taktik olarak tanımlar (2009, s. 55). Strateji ise daha geniş vadeli, içerisinde taktik de barındırabilen planlı eylemlerin bütünüdür. 1990'larda Garcia ve Lovink'in manifestolarında uzunca tanımladıkları taktiksel medya, kitle iletişim araçlarının sağladığı imkânlarla belli egemen konumlara taktiksel yöntemlerle müdahele eden, sanatsal, politik aktivizm biçimidir.

Bu çalışmada, ağ sayesinde dijital teknoloji ile üretilen sanat hareketlerinin elektronik mecraları nasıl kullandıkları, yapıtların hangi durumda taktiksel olduğu, hayatı; bilgiyi dönüștürdüğü ya da başlangıç amacından saptığı durumlar araştırılmıştır. Çalışmanın temelinde, taktiksel medya sanatının dijital ortamlarda ă̆ aracı ile yarattığı müdahaleleri siyasal estetik, ilişkisel estetik gibi teoriler ile okumak ve müdahalelerin yaklaşımlarındaki potansiyel çelişkileri ortaya çıkarmak amacıyla internet kaynakları ve literatür taraması yapılmıştır. Taktiksel müdahalelerin sanatla buluştuğu durumlar, eylem ya da üretim yöntemleri, gündelik yaşamda yarattığı etkiler incelenmiştir.

Taktiksel medyanın aktivizm ve sanat ile olan bağlantısı, dili kışkırtıcı bir şekilde kullanma, anlık etki yaratma, insanları organize etme, performatif, avangart özellikleriyle Dada, Sitüasyonist Enternasyonal, Fluxus, Happening gibi sanat akımlarına dayanır. Bu nedenle öncelikle çalışmanın ikinci bölümünde, taktiksel medya ve taktiksel medyaya tarihsel ve düşünsel açıdan zemin oluşturan sanat akımları ile temel bir çerçeve belirlenmiştir. Taktiksel medya müdahalelerinin kolektif bilinç oluşturan, toplumsal dönüşüm amacı taşıyan niteliği 1960-1970 tarihleri aralığında sanatı toplumsal dönüşüme yaklaştıran avangart hareketlerle ilişkilendirilmiştir.

Çalışmanın üçüncü bölümünde temelde askeri terimler olan taktik ve strateji kavramlarının ayrıca medya bağlamındaki anlamları açıklanmış, taktiksel medya ve taktiksel eğlence kavramları birlikte tanımlanmıştır.

Kolektif ve avangart tutumların yanı sıra taktiksel medya müdahalelerine başka bir açıdan bakıldığında, mevcut neoliberal düzeni onaylıyor gibi göründüğü durumlar çalıșmanın dördüncü bölümde Habermas'ın müzakere alanı olarak gördüğü (2003), Antonio Gramsci'nin kültürel hegemonya teorisinde egemen sınıfın uzlaşmacı yaklaşımı ile zayıf tarafın taktiksel tavrındaki hegemonyayı taklit riskine dikkat çekilmiştir (Gramsci, 1986; Ransome, 2010). Bu türde manipülasyon riski taşıyan müdahaleler nihayetinde amacından sapabilir, taktiksel eğlenceye de dönüşebilir, sistemin kendisini tekrar eder ve asıl amaç kaybolabilir. Claire Bishop'ın da eleştirdiği benzer bir risk, Nicholas Bourriaud'nun ilişskisel estetik teorisinde de mevcuttur (Bourriaud, 2005). Bishop'a göre, sanatsal estetik politik amaçların arkasında kaybolur (2007).

Hegemonya/Strateji'nin sahte uzlaşı tavrı ve taktiksel sanat müdahalelerinin mizahi yönünün öne geçmesi tehlikesinin karşısında Christian Scholl'ün çatışmacı ve Laclau ile Mouffe'un agonistik demokrasi kavramı ile karşıtlıkların devamlılığını ve muhalif durumlara rağmen çoğulcu, kolektif yaklaşımın önemi vurgulanmıştır. Ayrıca taktiksel sanat müdahalelerinin paradoksal yapıları gösterilmeye çalışılmış ve dijital karşılaşmalarla kamusallığın sağlanabileceği vurgulanmıştır (Scholl, 2015; Laclau ve Mouffe, 2015). Gramsci'ye göre ise; çatışmacı yaklaşım yerine toplumsal değişim ve dönüşüm, taktiksel olanın ancak rıza çerçevesinde mevcut hegemonya gibi davranarak asıl amacı kaybetmeden gerçekleşebilir.

Hem uzlaşmacı hem de çatışmacı politikaların taktiksel müdahalelerinin sanatsal pratikteki karşılığı olarak çalışmanın son bölümünde Paolo Cirio'nun Loophole for All çalışması ile incelenmiştir. Taktiksel medya müdahalesi olarak alanda tanınan otoritelerce sanat yapıtı olarak görülmüş ve ödül almış Loophole for All projesinin taktiksel tavrındaki söz konusu çelişkiler ve tehlikeler gösterilmeye çalışılmış; hegemonik olanla kurulan mesafenin dikkate alınıp, güncel teknolojik aygıtların dijital karşılaşmaları sağlayacak ortak hareketteki önemi vurgulanmıştır.

\section{Avangard Sanat'ta Hayatı Dönüştürme Olgusu - Anlık Deneyim}

Dada, Fluxus, Sitüasyonizm ve Happening akımlarının yaratıcı ortamlar organize etmeleri, savaşın ve politik durumların karşısında bir araya gelip teknolojik aygıtlarla üretimlerde bulunmaları gibi gündelik hayatın sınırlayıcı, kabul görülen anlamlarını altüst etmeye ve hayatı dönüştürmeye yönelik avangart tutumları, 21. yüzyıl sanat aktivistlerinin eylem ve üretim biçimlerinde yansımasını bulur. 
1916-1920 yılları arasında Triztan Tzara öncülüğünde dadacılar siyasi içerikli fikirlerini sanatsal yöntemlerle dile getirip, manifestolar ve mektuplar aracılı̆̆ıyla yayarak organize olmuş; Zürih, Köln, New York, Paris ve Berlin'de bir araya gelerek sözcükleri, nesneleri, gündelik hayata dair olanı kendi bağlamından kopartarak doğaçlama fikirler ve anlık eylemlerle, oyunsal unsurlarla birlikte yeniden anlamlandırmışlardır. Özellikle Almanya'da Dadaist gruplar anlamsızlığı yücelten ideolojilerini yaymak, baskın otoriteleri sarsmak adına; şarkı, kolaj, fotoğraf, poster, heykel, film, müzik, ses, gösteri, yürüyüş gibi her çeşit mecrayı kullanmışlardır.

1960'larda ortaya çıkan eylemlerini sosyopolitik mücadele olarak tanımlayarak Dada'dan ayrılan Fluxus akımı öncüleri, sanatın hayatı direkt etkilemesi ve değiştirmesi gerektiğini savunmuşlardır. Geleneksel sanata karşı sokak sanatı, ses enstelasyonu, performans vb. deneysel sanatsal eylemler ve etkinlikler düzenlemiştir. Geçiciliği, ânı ve süreci önemseyen sanatçllar, izleyicinin beklentisini boşa çıkarmak, şaşırtarak uyarmak gibi eylemlerle gündelik hayatı kısa bir süreliğine değişime uğratmışlardır (Antmen, 2008, s. 205). Dada'nın devamı niteliğinde olan 1959'daki eylemler happening (oluşum) olarak tanımlanırken; 1970'lerde ise performans sanatı, beden sanatı kavramlar ortaya çıkmış; tiyatro, müzik, ses, kolaj, şiir ve dans performatif eylemlerle ve kendin yap fikriyle bir arada bedeni de bizzat deneyim alanına çekmiştir. Böylece sanatçı hem nesne hem özne olarak var olmuştur.

1950’ler ve 1960'larda Guy Debord'un öncülüğünde avangard sanatçı gruplarının birleşmesiyle kurulan Sitüasyonist Enternasyonel grubu, kapitalizmin, modernizmin yarattığı gösteri toplumu ile mücadele edip, gündelik hayatta estetik ve politik devrimi amaçlamıştır. Kitle medyası teknolojileri aracılığıyla tüketim kültürünün giderek daha çok arzuyu körükleyen görüntülerin temsil ve manipüle edilerek dolaşıma sokulduğunu, hayatı gösteriye çevirdiğini savunmuşlardır (Lievrouw, 2016, s. 43, 44). İnsanların kendi hayatları için eyleme geçmesini durduran gösteriye karşı gündelik hayatın içinde, egemen ve medya tarafından yürütülen kültür ve politika temsillerini tersine çevirecek durumlar yaratılması gerektiğine inanmışlardır.

Dada'nın anti sanat tavrına benzer şekilde taktiksel medya da teorik ve akademik alanlara konu olmayı kabul etmez. Ayrıca, yasal ile yasal olmayanın sınırlarında dolaşan taktiksel medya sanatçıları için genellikle anonimlik esastır. Bir araya gelip örgütlenip, daha sonradan dağılıp tekrar başka bir eylem için başka gruplarla birlikte örgütlenebilirler.

\section{Taktik ve Strateji}

Clausewitz'in Savaş Üzerine başlıklı kitabında bahsettiği üzere (2003, s. 89); "Strateji ve taktik, zaman ve mekan içinde karşılıklı olarak birbirini etkileyen ve iç içe girmiş faaliyetlerdir." Taktik, savaş esnasında kısa vadeli müdahalelere dair bir teori iken; strateji savaşın bir bütün olarak ele alınan planlarını ve sonuçlarını ifade eder. Clausewitz, savaşı yaratıcılık gerektiren bir oyun olarak görür ve bu oyunda kazanabilmek için stratejilerin yanı sıra, taktiksel yöntemlerin önem taşıdığına dikkat çeker. Taktik kavramını günlük yaşama uyarlayan ve medya kültürünün terminolojisine kazandıran Michel de Certeau, 1974 yılında yayımlanan her türlü iktidarın kontrol mekanizmasına karşı günlük alışkanlık, tutum ve uygulamalar kuramını ortaya koyduğu Gündelik Hayatın Keşfi I adlı kitabında, düşmanın görüş açısı içinde düşman tarafından denetlenen uzam içinde gerçekleşebilen, firsatları değerlendiren bir hareket, kurnazlık ve zayıfın sanatı olarak tanımlar $(2009$, s. 115). Kazançlarını saklayabileceği bir uzama sahip değildir, ancak bir anın ona sunduğu olasılıkları değerlendirip, belli bir mülkiyete sahip erkin gözetiminde açtığı çatlakları son derece hassas ve özenli bir biçimde kullanması gerekir. Bu çatlaklar, taktiğin kaçak avlandığı yerdir ve sürprizlerini burada yaratır, en beklenmedik yerde ortaya çıkar. Certeau'ya göre strateji kavramı ise; “... (G)üçler arasındaki ilişkilerin ancak bir istek ya da erk öznesinin (işletme, ordu, kent, bilimsel kurum) yalıtılabilir olduğu anda gerçekleștirebileceği oyun ya da hesaplaşmadır (ya da manipülasyondur)" (2009, s. 113).

Dolayısıyla strateji, hedefi uzun vadede gerçekleştirmek için izlenen yol; taktik ise, uzun vadeli olan stratejik planların uygulandığı esnada kısa vadeli gerçekleşen ani, şaşırtıcı ve hesaplı hamledir. Certeu'ya göre stratejik olan, mekân kontrol altında tutulduğu takdirde gerçekleşebilirken, taktiksel olan ise farklı mekânlarda sınırları aşarak kısa müdahalelerle gerçekleşir. Taktiksel medya, mekânsal faaliyetlerden daha çok söylem alanlarının içine sızarak varlığını oluşturur. Bu nedenle, "Postmodern tarzda bir anarşistliğe bürünen taktiksellik, kapitalizmin işleyiş mantığını hicvetmek ve eleştirmek için kendini sürekli olarak dışarıda konumlandırırken aynı zamanda kendi anlamının üretimi için bu ilişkiye bağımlıdır" (Thompson, 2018, s. 144). 


\subsection{Taktiksel Medya}

Critical Art Ensemble üyelerinden Geert Lovink ve David Garcia tarafından tanımlanan taktiksel medya kavramı ise, teknolojilerin politik amaçlar için kullanımı, güç merkezlerine karşı, ağa bağlı bir ortamda sistematik mücadele biçimlerine dair bir terimdir (Critical Art Ensemble, 2001, s. 5). Sanatı hayata fiilen yaklaştıran Sitüasyonizm, Fluxus ve Dada gibi hareketlerde olduğu gibi taktiksel medya da avangardın özgürlük fikri, bozma ve deneyim alanları yaratma ilkesini benimser.

Bilgisayar, monitör, internet ve yazılım gibi teknolojik ortam ve dijital aygitlarla üretilen sanatsal çalışmalar, yeni medya sanatı olarak tanımlanırken; 1993 yılında The Next 5 Minutes konferansları sırasında Michel de Certeau'nun taktik ve strateji diyalektiğinde varoluş̧̧u bir estetik gören medya teorisyenleri Geert Lovink ve David Garcia, 1960'larda güçlü aktivist avangart hareketlerini gerçekleştiren Guy Debord'un başını çektiği Sitüasyonist Enternasyonel grubu, broşür, dergi, albüm, ses kayıtları gibi ucuz medya ile sanat temelli oyunsu, politik eserler üreterek; taktiksel medya kavramı ile her türlü iktidarın ve kapitalizmin hayatın her alanında belirdiği, yarattığı gösteri toplumu ve onun dayattı̆̆ı imgelere; mevcut düzene karşı çıkıp günlük yaşamda değişimi ve devrimi sanat aracılığıyla gerçekleştirmeye çalışırlar (Critical Art Ensemble, 2001, s. 4-5). 1999 yılında, Joanne Richardson taktiksel video aktivizminin fazlaca sokaktaki şiddete odaklandığını ve taktiksel medya teriminin Certeau'nun tanımından uzaklaştığını belirtir. Aynı dönemde, siber feminist ağ olan Old Boys Network, The Next 5 Minutes konferansının ikincisini düzenlendiğinde taktiksel medya araștırmalarının giderek Avrupa merkezli, beyaz adam etkinliğine dönüșmesinden rahatsız olmuş ve 2003 yılında, taktiksel medya laboratuvarları kurulması çağrısıyla uluslararası mail listesi ile hareketi Avrupa dışına taşımaya çalışmışlardır. 1999'da Seattle Mücadelesi, 2000'de Davos'ta gerçekleşen Dünya Ekonomik Forumu, Prag'daki IMF protestoları, 2001 yılında Québec City'deki Amerikalılar Zirvesi'ndeki çatışmalar, İsveç'te Avrupa Birliği zirvesi, G8 Protestolarında Cenevre'de çıkan çatışmalarla toplumsal ve kültürel aktivist hareketler yaratıcı direniş olanaklarını çoğaltmış ve Taktiksel Medya kavramı 2000'li yıllarda çok fazla izleyici, katılımcı sayısına ulașmasına rağmen 11 Eylül ve Bush hükümetinin militarist müdahalesinden sonra, popüler alternatif küreselleşme hareketleri ile dijital kültürel protestolar arasındaki dinamik bağlantılar zayıflamıştır (Medosh, 2016, s. 366). Bağımsız gazetecilik örneği olarak Indymedia, 1999 yılında Dünya Ticaret Organizasyonu protestolarında çevrimiçi medya aktivistleri tarafından başlatılan, dünya çapında ortak hareketin gönüllü katılımcıların pornografik yayın yapmamak gibi kurallar dışında editörsüz, dolayısıyla kısmen denetimsiz yayın yapabildiği bir harekettir (Kidd'den aktaran Lievrouv 2016, s.125). Move.org ve Change.org gibi oluşumlar da 2000 yllında özellikle Amerikan seçimlerinde yeni koalisyon oluşturmaya, seçim politikalarında alternatif oluşturmaya yönelik atılmış girișimlerdir. George W. Bush karşıtı mizahi ve ironik haberler yapan The Onion, Dünya Ticaret Örgütü basın toplantısına sızarak sunum yapan The Yes Men daha fazla kitleye erișerek halk desteğini arkasına alıp seçim politikalarına, kültürel ve toplumsal sermayenin işleyişine karşı net bir etki oluşturmaya çalışmışlardır.

2005 yılında Geert Lovink ve Ned Rossiter, Dawn of the Organised Networks (Organize Ağların Şafağında) ismindeki makalelerinde, taktiksel medyanın kısa süreli olması ve soruna dikkat çekip kaçan yapısının kapitalizmi beslediği düşüncesiyle, stratejik olanı ön plana çıkarmış ve gerçek bir hareketin oluşması adına dijital medyaya dair organised networks (organize ağlar) kavramını önermişlerdir. Dijital medyada ağın, yeni olasılıklar, yeni zamansallıklar ve yeni alanlar oluşturduğunu belirtmişlerdir.

Rita Raley'e göre ise taktiksel medya, egemen bir göstergebilim rejiminin müdahalesini ve bozulmasını, işaretlerin, mesajların ve anlatıların devreye sokulduğu ve eleștirel düşünmenin mümkün hale geldiği bir durumun geçici olarak yaratılmasını ifade eder $(2009$, s. 6). Raley, küreselleşme çağında sanatçıların teknoloji tabanlı müdahaleci aktivist eylemlerle kapitalizme, neoliberal küreselleşmeye meydan okuyan biçimde, politik bir direniş biçimi olarak göstergebilimsel açıdan sanatsal ve aktivist eylemleri inceler. Lovink ve Rossiter'ın aksine Raley'e göre, taktiksel medyanın işe yarayıp yaramamasından daha çok, medya projelerinin Paolo Virno'nun bir performans ya da etkinlik olarak arkasında nesne bırakmayan emeği ifade eden virtüözlük tanımıyla oluşturulan sosyal ilişkilerin yaratılmasına odaklanılması gerekir.

Genel olarak aktivist ve performans hareketlerle dijital medyanın bir araya geldiği taktiksel medya, a $\breve{g}$ ortamının desteğiyle deneysel, geçici ve oyunsu karakteriyle kolektif zekanın ve yaratıcılığın bir araya geldiği yeni mücadele alanları yaratmıştır. 


\subsection{Taktiksel Eğlence}

Karnaval tipi, eğlence yoluyla yaratılan ve mizah içeren protesto tipi ise taktiksel eğlence (tactical frivolity) olarak adlandırılır. Bu direniş yaklaşımında, popülariteye daha yakın olabilecek bir mesaj yayılır ya da muhalefet fikir eğlenceli bir şekilde söylenir veya uygulanır (Vila and Expósito, 2007). Taktiksel eğlence, Bakhtin'in orta çağ festivallerini inceleyerek teorileştirdiği ve karnavalesk olarak ifade ettiği toplumsal rollerin, hiyerarșinin, yasakların bir süreliğine askıya alındığı; farkın mizah yoluyla reddedildiği șenlik ortamının çağdaş versiyonu olarak görülebilir. Taktiksel eğlence anlarında parlayan bombalar, süslü malzemeler, havai fişek, hicivli şarkılar ve manifestolar protesto aracı olarak kullanılarak hoşnutsuzluğu açıkça ifade eden ve adaletsizliği taktiksel ve yaratıcı eylemlerle direkt mesajlar içeren eylemlere göre daha etkili şekillerde görselleştiren bir iletişim biçimi kurulur. Mizahın ve yaratıcılığın rolü, politik eylemleri aynı zamanda sanatsal avangart hareketlere dönüștürür.

The Eclectic Electric Collective sanatçı grubu, "Sanat, topluma tutulan bir ayna değil, ancak ona şekil verecek bir çekiçtir." Fikrinden yola çıkarak Almanya'da protestolarda polise karşı kullanmak üzere metalik, yansıtıcı malzemeyle büyük balon çekiç, küp vs. üretmişlerdir. Bu büyük yumuşak nesneler, protestocular ve polisler arasında gidip gelerek şiddeti oyunsallaştıran, hatta voleybol oyununa dönüștüren bir yapıya bürünmüşlerdir (Duarte, 2014).

Pink Bloc, Pink Silver, Fluxus Billionaires for Bush, the Yes Men, the Laboratory of Insurrectionary Imagination, the Clandestine Insurgent Rebel Clown Army, Orange Alternative gibi aktivist gruplar, gücün ve şiddetin karşısında taktiksel eğlencenin karakteri olan mizahı, oyunu, ironiyi, absürtlüğü kullanarak yaratığı taktiksel müdahalelerde bulunmuşlardır.

Medya ve enformasyon teknolojileri ise, toplumsal hareketlerde bilgilendirme, iletişim kurma, harekete geçirme, bir araya gelme gibi olanaklar sağlarken; hacker, aktivist ve sanatçllar için coğrafi ve yasal sınırları kısmen așan, direkt sanal ortamda eylemde bulunabilmelerine zemin olușturur. Böylece protestoları, aktivist hareketleri yine çoğunlukla mizahi yöntemlerle çevrimiçi ortama taşımışlardır. İsyan siteleri, e-posta spamları, web saldırıları, bilgisayar virüsleriyle büyük şirketlerin yasa dışı oyunlarını ortaya çıkaran, işçilerin hakkını savunan projeler üretmişlerdir.

Taktiksel eğlenceye göre, organize edilen eylemler otoriteyle doğrudan çelișen yapıda gerçekleșmediği için, zamanı ve otoriteyi durduran; aynı zamanda karşı kontrolü ve şiddeti dönüştüren; dolayısıyla çarpışmaların ertelendiği veya yumuşadığı küçük çaplı ütopik anların oluşmasına sebep olur. Diğer bir açıdan ise taktiksel eğlencenin iyimser yapısı, tüm kutlamaların görselliği ve şölen ortamı protestoyu amacından saptırabilir ve asıl mesele coşku içinde kaybolabilir.

\section{Karşılaşma Alanlarında Taktiksel Sanat Müdahalelerinin Politikası}

Taktiksel medya, eleştirel kültürel çalışmaların, online bağımsız gazetecilik ağı Indymedia gibi uygulamaların yanı sıra; yaratıcı, üretken, oyuncu, otoriter yapıların baskın yapısına karșı durum yaratması, aldatan, korsan, şok edici ve provokatif, performatif nitelikteki avangart eylemlerinin kısa ömürlü olması gibi özellikleriyle çoğunlukla aktivist sanat hareketleriyle ilişki kurar. Aktivist sanat, pragmatist bir yaklaşımla temelde sitüasyonistlerin durum yaratmak olarak tanımladığı gündelik hayatın normal akışının sınırlarını aşan, genel siyasal ve toplumsal koşulları tamamen değiştirmeye yönelik durumlar yaratmaya çalışır. Sanatı, aktivist alana çeken temel düşünceye göre izleyici, demokrasi ve özgürleşme umuduyla katılımcıya dönüşür. Sanatçı figürü, ötekiyle beraber yıkarken inşa eder, eylemini diyalog ve ilişkiler üzerinden estetize eder. Bishop'ın (2015), Katılımcı Sanatın Açmazları başlıklı makalesindeki ifadesine göre; gösteri içinde bir toplumda sanatsal faaliyet, edilgin seyirciler tarafından tüketilecek nesneler üretmekten ibaret olamaz: "Gerçekliğe karışacak, toplumsal bağı onarmaya yönelik küçük de olsa adımlar atacak bir eylem sanatı olmalıdır." Taktiksel medya sanatı, avangart aktivist hareketlerin hayatı tümden ele geçirme, demokrasi ütopyasından, büyük devrim fikrinden daha çok küçük, mikro devrimi, geçici müdahale ve an yaratmayı amaçlar.

Debord (1996), Gösteri Toplumu'nda bahsettiği gibi sanatı gösterilen şey aracıllğılyla kapitalizm tarafından dolayımlanan ilişkiler biçimi olarak görür ve sanat eserini izleyen, eserin karşısında pasif konumda bir özne hiçbir şeyi değiştirmez. Ancak gerçek bir deneyim için kamusal alanda aktif öznelere ihtiyaç vardır. Sanatı seyirlik halinden çıkartıp, işlevsel nitelik kazandıran avangart katılımcı hareketler, kamusal alan içerisinde farklı olanaklar ve yeni alternatifler üretmeye çalışır. Çalışma başlığında belirtilen karşılaşma alanları, dijital ortamlar ve teknolojik aygıtların aracıllı̆ı ile veya bizzat internet ortamında kurulan 
iletişim alanlarıdır. Medya araçları ve internet ortamı, sanatsal hareketlerin elektronik ortamlarda hızla yayılabileceği taktiksel müdahalelere elverişli, alternatif bir ortam ve geniş bir etki alanı yaratır.

Toplumsal hayatın içinde ortak bir sözün oluşması için, insanların bir araya gelip sözlerini ifade edebildiği, örgütlenebildiği, tartışabildikleri ve fikirlerini yayınlayabildikleri alanı kamusal alan olarak tanımlayan Habermas (2003), iletişim araçlarını iletişimin ve etkileşimin artması açısından değerli bulur. Habermas'ın, bir araya gelip fikir paylaşımlarının yapıldığı ve iletişimsel eylem olarak tanımladığı ortam, insanların fikirlerini herhangi bir baskı altında kalmadan ifade ettikleri, hiyerarşinin kaybolduğu ve farklılıklara rağmen tüm şartların eşitlendiği bir kamusal alandır. İletişimsel eylem mekânı olarak sanal ortamların da katılımcıların gönüllü olarak eşit bir zeminde var olabildiği, çoklu iletişime açık ve çözüm önerilerinin üretilebileceği müzakere alanları, kamusal alan olarak görülebilir.

Kürator ve teorisyen Nicolas Bourriaud (2005), 1990’ları işaret ederek altermodern devre geçildiğinden beri sanatsal üretimin insan etkileşimlerinin oluşturulmassına yönelik, ötekinin de bulunduğu, uzlaşmacı, toplumsal kanalları açan ilişkisel estetik olarak tanımladığı ve anlamın toplu halde ortaya konduğu özneler arası ilişkilerden oluştuğunu belirtir. Taktiksel medyada kolektif bilincin ve ortak hareketlerin karşılaşmalar açısından önemli bir yeri vardır. Sitüasyonist düşüncenin devamı gibi sanatçı şehri ve hayatı kendi malzemesi olarak görür, süreçlere ve ilişki biçimlerine müdahale eder. Eylem mekânları için tüm öznelerin kendi istek ve doğrultusunda aynı zeminde karşılaştığı, aktör-seyirci; üretici-tüketici arasındaki sınırların eridiği mekânlar oluşturmak ister.

Scholl, müdahale edilen ve kesintiye uğratılan eylemlerin şimdi ve buradalık fikrine ve bireyselliğe odaklanmasını Punk kültüründeki kendi müziğini kendin yap (Do It Yourself) pratiğine bağlar. Punk kültürü ile başlayan kendin yap pratiğinin giderek daha sonradan kültürel üretim alanında, işgal hareketlerinde, küresel anarşist eylemler ve aktivist/taktiksel sanat müdahaleleri için de kullanıldığını belirtir (Scholl 2015, s. 205). Scholl'ün şimdi ve buradalık fikri, dijital ortamlar sayesinde sokakta ya da mekânlarda kulaktan kulağa gerçekleştirilen eylemlere göre, daha az riskle var oluşu sağlar ve daha hızlı örgütlenme, üretim ve müdahaleye izin verir.

Christian Scholl, sanatsal müdahalenin aktivizm içindeki kullanımını olayların bildik akışını kesintiye uğratma (disruption) ve çatışma (confrontation) olarak iki farklı aktivizm mantığına dayandırır. Scholl, iki aktivist mantığının bedenleri, mekânı, zamanı, sesleri, imajları ve görselliği bir araya getirmesinin farklı dinamiklerini ortaya koyar. Kesintiye uğratma daha çok toplumsal bilginin sekteye uğratılmasıyla ilgilidir. Bu şekilde tipik olarak egemen ya da aktivist bilgi sürecinde geçici bir yarık açlır. Örneğin; Sokakları Geri Al eylemlerinde otoyollar işgal edilip, karnaval alanına çevrildiğinde bu eylem otoyola ilişkin bilgiyi kısa bir süreliğine altüst eder. Scholl'e göre aktivistlerin bu türden kesintiye uğratma faaliyetlerindeki amacı, zamanda ve mekânda herkesin anlayacağı bir jest yaratıp, mümkün olan başka dünyayı örneklemektir. Scholl'ün, çatışma olarak kategorize ettiği müdahaleler, var olan bilgiyi ya da olayı asker kıyafetleri giymiş Palyaçopistler gibi temsili olmayan, -mış gibi olma ve ne olmadığını tanımlayan eylemleri, neoliberal siyasetin savunucularına ait bir etkinlik ortamına yumurta, pasta vb. eşya fırlatılan, etkinliği sabote edecek başka bir eylemi içine alan hareketleri kapsamına alır (School 2015, s. 197-225).

Wilson (Hakim Bey), T.A.Z Geçici Otonom Bölgeler adlı kitabında, ontolojik anarşi kavramına dayanarak akışta durum yaratmayı ve anlık devrimi önemseyen Scholl'ün yaklaşımına benzer hayatta kalmaya yönelik taktikler önerir. TAZ, kesintiye uğratılan, mevcut durumun geçici olarak duraklatıldığı, kısa süreli özgürleşme anlarının yaratıldığı, geleneksel anarşist yaklaşımların yerine, ağ biçiminde örgütlenen, merkezsiz, hareketli, coşkulu karşı mücadelelerden oluşan bir anarşist özgürlükçü yaklaşımın, karşılıklı yardımlaşma ve dayanışmasına dayalı kolektif birlikteliklerini öne çıkaran bir anarşizmin onaylanmasıdır. Kitabın Şebeke ve Ağ bölümünde, tarihsel açıdan kitabın yazıldığı tarih göz önünde bulundurulduğunda, tam olarak günümüz teknolojisindeki olanaklardan bahsetmese de şebekenin hiyerarşik olmayan, yatay yapısıyla sanal bir zaman ve mekânda korsanlığa, manipülasyona açık karşı-şebeke alanı yaratılabilen alternatif ve otonom bölge olarak görür (Wilson 2009, s. 157-167).

Teknolojik bağlamda ağ, yapısı gereği kurulan hızlı iletişim olanakları sayesinde geniş kitleye erişim sağlayarak kolektif hareketlere zemin oluşturmuştur. Ancak dijital ortamda kurulsa da rengarenk ve coşkuyla gerçekleşen taktiksel müdahaleler çatışma yaratmadığında karşı çıkmaya çalıştığı düzeni yeniden üretip, mevcut olanı destekler hale dönüşme riski taşır (School 2015, s. 201-202). Çatışmada eylemin niteliğine bağlı olarak iktidarın kendisini taklit etme riski, karnaval ortamı yaratan bir çatışma halinde de görülebilir. Bu durumda eylemde bulunan sanatçı, kitle kültürüne sanatsal yöntemle direnerek iktidar ve sermaye yapılarına karșı mücadele ettiği yanılsamasına kapılabilir. 
Claire Bishop, Antagonizma ve Illişkisel Estetik adlı makalesinde Ernesto Laclau ve Chantal Mouffe'un Hegemonya ve Sosyalist Strateji: Radikal Demokratik Bir Politikaya Doğru adlı kitabını referans göstererek, katılımcı sanat için estetiğin sanat üzerindeki otoritesinin kaybolduğu, sanat alanından çıkılıp, pratiklerin politik projelere dönüştüğünü belirtir (Bishop, 2007, s. 46). Bishop, söz konusu politik projelerin sanatsal niteliklerinin ahlak kriterleriyle değerlendirilip, iyi niyetlerin ardında kalındığını ifade eder, bu tür girişimlerin yüceltilmesini eleştirir. Bishop'a göre ilişkisel yapıt, uzlaşmacı ve iyimser yönüyle iki tarafın bir ortak zemin paylaşmayan, düşmanlığa dayalı, öteki ile olan ilişkiye dair olan antagonizma kavramına aykırı bir yapıdadır. Siyasal olanın kamusal müzakere ve özgürlük alanı olarak gören teorisyenlerin yanı sıra, antagonizma ve çatışma alanına daha yakın fikirleri olan Laclau ve Mouffe Radikal Demokrasi kavramıyla öne sürdüğü agonistik siyasette ise çatışmayı, bölünmeyi ve itirazları demokrasinin koşulları olarak görür (Laclau ve Mouffe 2015, s. 39). Bu yaklașıma göre; ancak demokratik bir toplumda dost düşman ilişkisine dayanan antagonizmanın, agonizma'ya dönüştüğü, farkların bir arada varlığını, karşıtlıkların düşmanlığını çatışarak değil, karşıtlıklarla beslenerek mücadeleye dönüștürmeye yönelik potansiyel taşıyan uzlaşı yöntemi değerlidir (Mouffe, 2015, s. 28). Habermas'ın ve Bourriaud'nun müzakereci yaklaşımlarının aksine, Bishop da Laclau ve Mouffe'un önerdiği gibi dost düşman kavramlarını ortadan kaldırmadan, muhalife rağmen birlikteliği ve çoğulcu yaklaşımı benimser.

Bishop, Laclau ve Mouffe gibi İtalya'da faşizm karşıtı stratejileri ile devrimci, sosyalist önerileri olan Marksist filozof Antonio Gramsci, işçi sınıfının kolektif bir bilinç yaratması ve kendi hegemonik aygıtlarını üretip yaygınlaştırması gerektiğini savunur (Moget'dan aktaran Gramsci, 1986, s. 73, 74). Bu doğrultuda gerekirse ittifak görüntüsü altında burjuvaziyle iş birliği yapılmasını önerir. Ekonominin tek belirleyici unsur olmadığını ifade eder ve Marksist düşünceyi kültürel hegemonya kavramı ile geliştirir. Kültürel Hegemonya ile burjuvazi kurumlar aracılığıyla, gelenek, eğitim, tarih, dil vb. kültürel değerlerle baskın (zor) ancak uzlaşmacı (rıza) görünümlü bir tutumda ortak duyu düşüncesi yaratıp, egemenliğini topluma kabul ettirir ve ekonomik eşitsizliği sürdürmeye devam eder (Ransome, 2010, s.179,180) Gramsci'ye göre burjuvazi karşısında, kendi organik aydınları ile karşı kültürel hegemonya üretilmesi gerekir (s. 241). Ancak bu yolda üretilen taktiksel ve stratejik müdahalelerle ideolojik ve kütürel anlamda üstünlük sağlanabilir. Gramsci, egemen sınıfın uzlaşmacı tavrındaki stratejiyi tersine çevirmek ister. Antonio'nun bu düşüncesinin karşıllı̆ıı taktiksel, aktivist sanat müdahalelerinde karşıllı̆̆ını bulduğu söylenebilir. Böylesi bir karşı hegemonyanın oluşabilmesi için zayıf olan tarafları ilüzyonist fikirlerden (örneğin; işçi sınıfını kendisine verilen sınıfsal üstünlük vaadi) arındıracak aydınlara, medya organlarına, sanatsal eylemlere ihtiyaç vardır.

Hardt ve Negri de çokluk kavramıyla, tüm farklılıkların kendini özgür ve eșitçe ifade edebileceği; maddi olmayan emeği önemseyen, birlikte yaşayıp ortak çalışabilmeyi mümkün kılan bir karşılaşmanın araçlarını sağlayan ağ olarak, sermayenin kontrolünden kısmen bağımsız yeni bir direniş biçimi tanımlar (Hardt ve Negri 2001, s. 59, 84, 96). Maddi olmayan emek, bilgi, enformasyon, iletişim, ilişkiler ve duygusal ifadeler üretir ve bu üretimi ifade eden ağın merkezsiz, sınırları belirsiz, dağınık yapısı Ciapas'ta 1990 'da ortaya çıkan Zapatista Ulusal Kurtuluş Ordusu (EZLN)'nda görülebilir. Bir kolektif özne örneği olarak Zapatistalar, internet ve iletişim teknolojileri sayesinde ideolojilerini, söylemlerindeki ironiyle kendi aralarındaki hiyerarşileri sürekli dağıtıp, otoriteyi merkezsiz kılmışlardır (s. 102, 122). Kuzey Amerika Serbest Ticaret Anlaşması'na karşı gerçekleştirdikleri protestolarıyla interneti bir mücadele alanı olarak kullanarak düzenledikleri küresel çaplı buluşmalar, G-8, Dünya Ticaret Örgütü, IMF gibi konferanslara karşı gerçekleșen hareketlere öncü olmuşlardır. Tarihsel açıdan bakıldığında Zapatistaların kurduğu ağ, 1994'teki internet ve teknoloji olanaklarına göre erişimin, görünürlüğün ve denetimin yetersiz kalmasının ve hikayeleriyle kurdukları iletişim taktiği ile yarattıkları ortak kaygının aynı dönemde tüm dünyada gerçekleşmesinin etkisiyle geniş çaplı etki oluşturmuş, sanal ortamda mevcudiyetini koruyabilmiştir.

Taktiksel müdahalelerde dijital ortamların olanaklarıyla, sanal ortamda ya da kamusal alanda gerçekleşirken ortak hareket etmek önem arz eder. Richard Sennett'in (2012, s. 24) "özgürlük, iş birliği tecrübesine bir sonuç olarak katılır" yaklaşımıyla, aktivist ve sanatsal yöntemlerle bireyleri özgürlüğe kapı aralayan ortak bir paydada buluşturmaya çalışır. Neoliberal düzenin siyasal yapılarını alt üst etmeye yönelik gerçekleştirilen ilişkisel veya katılımcı toplumsal ve kültürel hareketler kendi içlerinde birlik yaratma potansiyeli taşır. Ya da müdahalede bulunulacak kurumlarla veya yapılarla aynı dili kullanarak, kolektif yaklaşımla antagonizmaya rağmen agonizma yaratılarak toplumsal estetik yöntemlerini tahribe, yıkıma yönelik araç olarak görür. 


\section{Dijital Ortamda Taktiksel Sanat Müdahalesi Olarak Paolo Cirio'nun Loophole for All Projesi}

İnternet üzerinden, iletişime ve dönüşüme açık bir örnek olarak taktiksel müdahalelerde bulunan İtalyan hacker sanatçı Paolo Cirio, çağdaş ekonomik, sosyal ve politik sistemler üzerine çalışıp, bu sistemlerin sanatsal bağlamda nasıl yeniden düzenlenebileceğini araştırır. Cirio, 2013 yılında ürettiği Loophole for All (Herkes için Yasal Boşluk) çalışması ile Cayman Adaları'nda 200000'den fazla özel şirketin yasal olmayan finansal çalıșma politikalarını hükümetin resmi arşiv web sayfasını hackleyerek ifșa etmiștir (bkz. Şekil 1 ve Şekil 2). Karayipler'de Birleşik Krallığa bağlı Cayman Adaları'nda kara para aklamanın, vergi kaçırmanın yöntemlerini Loophole4All.com web sayfasında tüm iş dünyasına açarak küresel finansal düzenine ironik bir müdahalede bulunmuştur. Cayman şirketlerinin gerçek kimliklerini 0,99 avro karşılığında satışa çıkarmış ve dört adımla bir şirketi gasp etmenin yolları sloganıyla şirketleri tekrar satışa çıkarmıştır. İlanı gören kişilerin yapması gereken tek şey, şirket ismi arayıp, siteye üye olmak, daha sonrasında șirketi satın almak ve tapu sahibi olup fatura kesmeye bașlamasıdır. Ayrıca herhangi bir kiși 0,99 avro karşılı̆̆ında şirket tapusunun yanı sıra şirketin tüm yetkili mail adreslerine erişim de sağlayabilmiştir. Cirio, şirket tapularına Cayman Adası resmî web sayfasını hackleyerek direkt erişimi sağladığı için, web sayfasında yayınladığı şirketlerin tapularını ve şirketlerin ilişki ağlarına dair belgeleri çevrimdışı ortamdan sanat galerisine taşımıştır. Kurduğu web sitesinin üzerinden kazandığı parayla ise kendi önerdiği yöntemle kendisi de şirket kurmuştur (Cirio, 2013).

Cirio'nun, denizaşırı finans merkezlerin verileri ve büyük şirketlerin yasal boşluklara dayanarak dokümantasyonunu yayınladığı belgeler, Cayman Adası hükümet yetkilileri, uluslararası medyayı, hukuk şirketleri ve bankaları, söz konusu şirketlerin gerçek sahiplerinin, vergi kaçırmak isteyen işletmeleri harekete geçirmiştir. Birçok bireysel ve tüzel kişi Cirio ile iletişime geçmiş ve çalışma büyük bir tepki oluşturmuştur. Cirio, kimlik hırsızlığı ile suçlanarak birçok tehdit içerikli mail almış, ancak şirketlerin esasında vergi kaçırarak kendileri daha büyük suç işlediği için mailleşmeler daha sonradan uzlaşmaya yönelik yazışmalara dönüşmüștür.

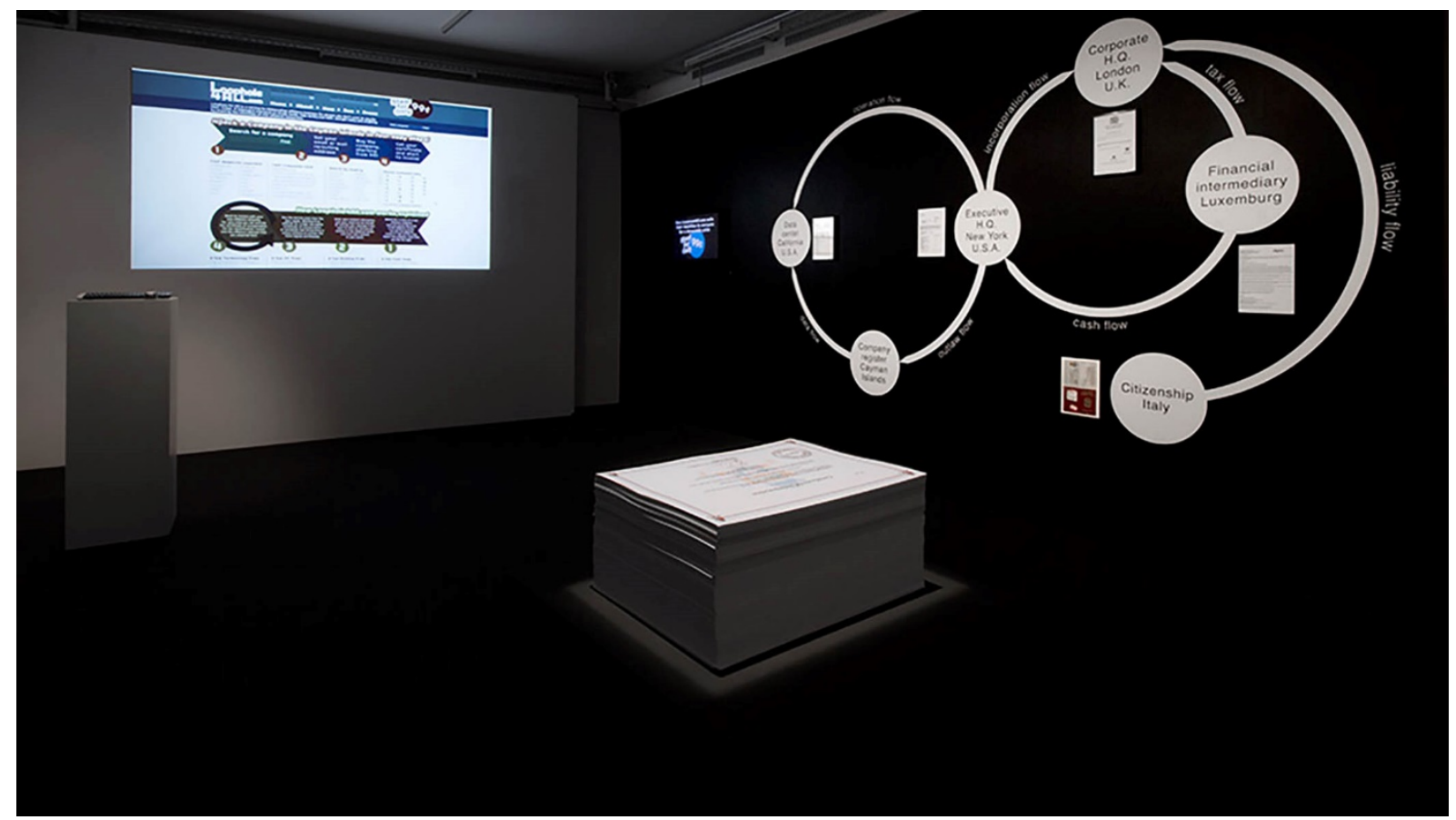

Şekil 1. Loophole for All [Enstelasyon], Kişisel Sergi, Aksioma Proje Alanı, Lübliyana, Slovenya Cirio, P. (2013).

Şirket yöneticileri, şirketlerin yeni sahipleri ve hukuk büroları ile Cirio arasında mail yoluyla çatışmaya dönüşen yazışmalar, nihayetinde denizaşırı finans desteği veren, birçok şirketin vekalet sahibi hukuk bürosunun Cirio'nun sanat yapıtını koleksiyonlarına katmasıyla son bulmuştur. Cirio'nun medya performans sanatı olarak nitelendirdiği Loophole for All projesi kısa bir süreliğine de olsa, tehdit unsuru olarak taktiksel bir yaklaşımla telif hakkı, gizlilik, ekonomik eşitsizlik gibi kavramlarla yasal sınırlar çerçevesinde dünya çapında finansal güce sahip şirketlere meydan okumuştur. Proje süreci boyunca ise 
dijital karşılaşmalara, mail yoluyla sanal çatışmalara sebep olmuş, yeni bir ilişkisel yapıta dönüştüğü düşünülebilir. Aynı zamanda internet ortamında bir kamuoyu oluşmasını sağlamış, Scholl'ün kastettiği biçimde bedenler üzerinden kurulan hayatın akışı içinde bir kesinti veya bire bir çatışma alanı oluşmasa da esasında oluşturduğu ağ sayesinde iş dünyasını harekete geçirerek "hayatın kendisine dokunan" taktiksel bir müdahale gerçekleşmiştir(Cirio, 2013).

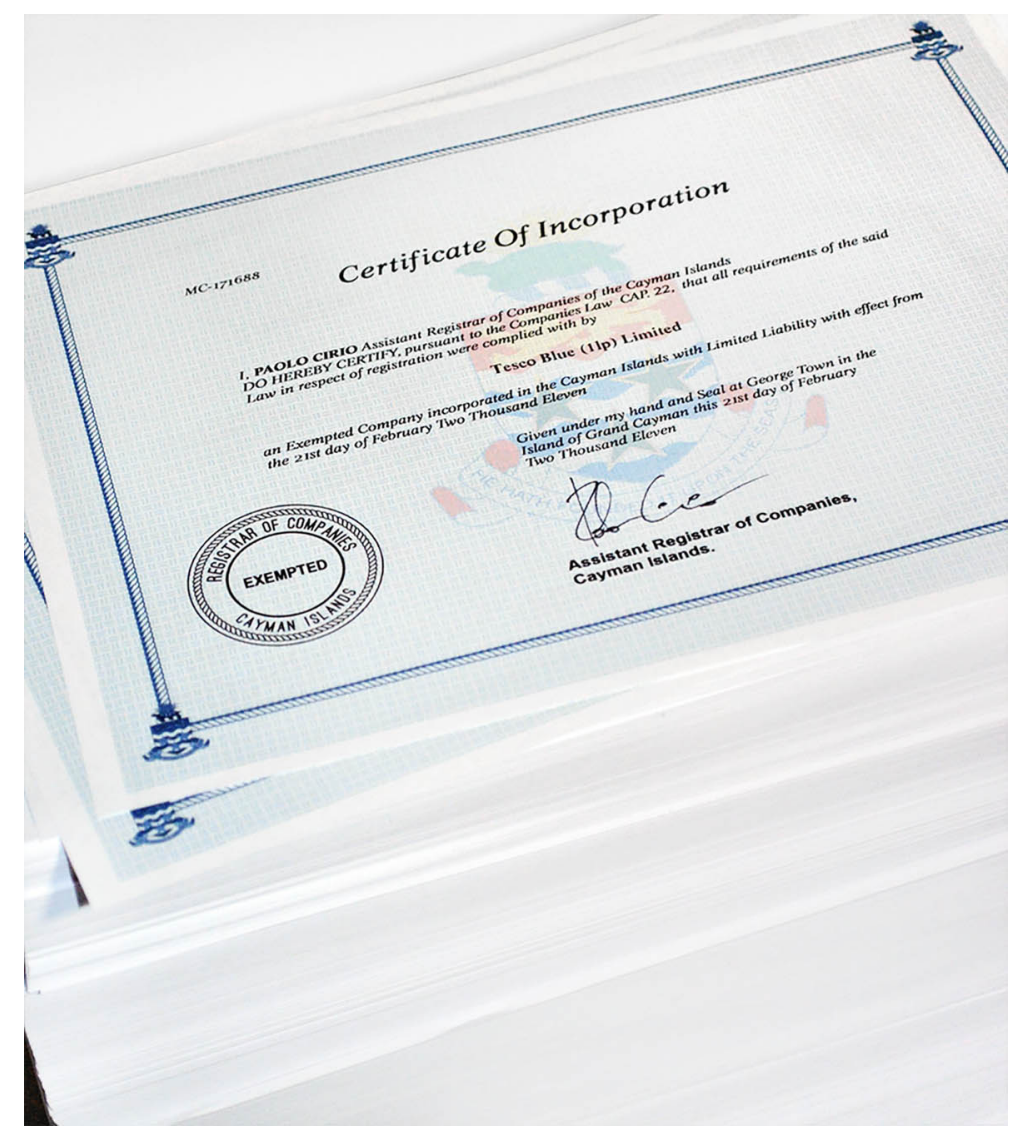

Şekil 2. Birkaç bin Cayman Adası şirket tapusu [Enstelasyon], (Loophole for All sergisinden), Cirio, P. (2013).

Cirio'nun çalışması, Scholl'ün aktivist yaklaşımlarına göre yasal olana dair bilgiyi kesintiye uğratarak sanal ortamda kısa süreli ancak uluslararası alanda etkili bir hareket yaratmıştır. Aynı zamanda kimlik ifşalarından daha öte bilgiyi ortaya çıkarma yaklaşımı ile, içeriği ve yöntemi herkesin erișimine açan, herkes için önem arz edebilecek, evrenselci toplum düşüncesi mevcuttur.

Çalışmaya başka bir açıdan yaklaşıldığında, sanatçının kısa süreliğine yaratmaya çalıştığı şirketler arası demokratikleştirme adımı, toplumsal iyiyi hedefler gibi görünse de bir yandan da yasal açığın reklamı haline gelmiştir. Üstelik kendisi bu proje için kurduğu web sitesi üzerinden satış yaptığl göz önünde bulundurulduğunda, aynı yöntemde kurduğu ancak kendi verilerini gizlerken, tüzel kişilerin verilerini ifşa etmiş, gizlilik ihlali yanı sıra tekrar satışa sunarak kimlik kopyalamaktan esasında suç işlediği düşünülmüştür. Ayrıca dünya çapında büyük şirketlerin vergi kaçırdığı, vergi kaçırma yöntemlerinin haritasının ve isimlerin direkt ifşa edilmesinden önce de bilinen bir bilgi olduğu söylenebilir. Genellikle hacktivist yaklaşımı sebebiyle eleştirilen sanatçı, şirketlere karşı gerçekleştirdiği müdahalelerin sanatsal pratikten başka bir niteliği olmadığını savunur. Ancak ifşa ettiği harita daha geniş ölçekte ele alındığında, Cirio'nun müdahalesinden önce şirketler tarafından desteklendiği ve çalışmasının planlı bir girişim olması da bir ihtimal dahilindedir.

\section{Sonuç}

Bu çalışma kapsamında, taktiksel medya alt kavramları, tarihçesiyle ve sanatsal pratikteki yöntemleri incelenmiştir. 1990’lardaki söz konusu yapılara karşı tüm dünyada ortak yaratıcı müdahale girişimleri yarattıkları mikro devrimleri aralayan yöntemler olarak görülmüştür. Taktiksel medya pratikleri; ilişkisel, sanatsal, siyasal teorilerle ilişkilendirilerek ve sanal ortamda güncel bir örnek Paolo Cirio'nun 
Loophole4all projesi çerçevesinde ele alınmıştır. 1990’lardaki örneklerde kısıtlı medya araçlarıyla deneyimlenen taktiksel medya müdahalelerinin, 21. Yüzyılda çevrim içi merkezi olmayan ağların ve teknolojik aygıtların çoğalması sayesinde daha hızlı ve mümkün kılındığı düşünülebilir. Ancak diğer bir açıdan çoğalan imkanlar sayesinde Loophole4all projesiyle görülebileceği gibi, her bir izin kaydedildiği, daha karmaşı ilişkiler ağı içinde müdahalenin asıl niyetinin, okunması daha zor bir konuma evrildiği gösterilmeye çalışılmıştır.

İletişim ve bilgi teknolojilerinin çoğalması, bireysel alanların önünü açtığı kadar, bu alanların da özgür ve demokratik nitelikleri tartışmalıdır. Nitekim 1990'lara göre 2000'li yıllarda medya, internet bitmeyen bir enformasyon dalgası, gelișen denetleme imkânları sayesinde devletin ve sermayenin izin verdiği kadar müdahaleye açık bir durumdadır. Büyük şirketlerin, medyanın hayatın içindeki dolayımlı varlıkları, hiyerarşilerin daha çok belirginleştiği bir ağ yaratır. Dolayısıyla yaratılan ağ ortamında da güncel teknoloji sayesinde her türlü deneyimin gizli izleyicilerin ve takipçilerin bakıșının altında varlığını sürdürdüğü söylenebilir. Ancak yine de aynı olanaklar sanatla, ironiyle, taktikle hala erișilebilir kılınabilir. Dolayısıyla hem çatışma hem uzlaşma tavırlarının iç içe geçtiği taktiksel/sanatsal politikalarla, karmaşık ilişkiler ağını gösterebilecek bilgiye ulaşmak mümkün olabilir. Bu nedenle yine de taktiksel/sanatsal medya hareketleri, tahakküm modelini durmaksızın yeniden kuran toplumsal ve kültürel sermayeye tamamen direnç gösteremese bile yarattığı küçük girişimlerinin değerli olduğu, güncel sanatsal pratiklerine tekrar bakmayı öğrettiği, tüm denetime rağmen en azından neyin gerçek direniş, neyin aktivizm olduğu hakkında düşünce pratiği açısından öğretici ve yaratıcı olduğu söylenebilir.

Başka bir deyişle, sermayenin az sayıda kapitalistin elinde toplanması üretim araçlarının ademi merkezileşmesine, üretim ilişkilerinin de merkezileşmesi eşlik etmiştir. Bu paradoks nedeniyle, özerk kaynak, ağ ve altyapı oluşturmaya olan ilgi her zamankinden daha güncel hale gelmiştir. Burada asıl mesele geleneksel medyaya bir alternatif yetiştirmek değil, hegemonik alanı yeniden ifade etmek için taktiksel müdahaleyle Gramsci'nin de önerdiği gibi kültürel hegemonyanın içinde zayıf olanın kendi medyasını, kendi aygıtlarını yaratmaktır. Dolayısıyla eğer amaç, başka bir bilgi- iktidar olanağı ve özerkliğin yaratılması ise esasında her eylemin bir sorumluluk taşıdığı; dolayısıyla taktiksel, sanatsal, aktivist nitelikte eylemlerin, hegemonik olanın otoritesiyle kurulan mesafenin ve ilişkisinin önemli bir yeri olduğu gösterilmeye çalıșılmıștır. Söz konusu eylemler kendin yap, vur-kaç, hackleme gibi yöntemlerle sermayenin, iktidarın kendisini tekrar etmekten sakınılacak girişimlere ve bu girişimlerin iktidar yapılarıyla ilişkilerini açığa çıkaracak bilgiye ihtiyaç vardır. Dijital ağ ortamı, tüm farklılıklarla ortak paydada buluşulabilecek etkileşim sağlayarak tamamen ahlaki veya sanatsal söylemlerin içinde kaybolmayan projeler, hegemonya kavramının karşısında alternatif toplumsal ilişkiler kurulmasında zemin oluşturabilir.

\section{Kaynakça}

Antmen, A. (2008). Sanatçılardan yazılar ve açıklamalarla 20. yüzyıl batı sanatında akımlar, Sel Yayınları.

Bishop, C. (2007). Antagonizma ve ilișkisel estetik- olasılıklar, duruşlar, müzakere, güncel sanatta kamusal alan tartışmaları (N. Dikbaş, Çev.). İstanbul Bilgi Üniversitesi Yayınları.

Bishop, C. (2015). Katılımcı sanatın açmazları. https://e-skop.com/skopbulten/katilimci-sanatinacmazlari/2634

Bourriaud, N. (2005). İlişkisel estetik (S. Özen, Çev.). Bağlam Yayınları.

Certeau, M. (2009). Gündelik hayatın keşfi I, eylem, uygulama, üretim sanatları. (L. Arslan Özcan, Çev.). Dost Yayınları.

Clausewitz, V.K. (2003) Savaş üzerine. (Ş. Yalçın, Çev.). Eriş Yayınları.

Cirio, P. (2013, Şubat). https://paolocirio.net/work/loophole-for-all/

Critical Art Ensemble. (2001). Digital resistance explorations in tactical media. Autonomedia Press.

Debord, G. (1996). Gösteri toplumu. (O. Taşkent ve A. Ekmekçi, Çev.). Ayrıntı Yayınları.

Duarte, S. (2014, Temmuz). https://www.vam.ac.uk/blog/disobedient-objects/tools-for-action-interviewwith-artur-van-balen.

Gramsci, A. (1986). Hapishane defterleri - seçmeler. (K. Somer, Çev.). Onur Yayınları. 
Habermas, J. (2003). Kamusallığın yapısal dönüşümü. (T. Bora ve M. Sancar, Çev.). İletişim Yayınları.

Hardt, M. ve Negri, A. (2001). Imparatorluk. Ayrıntı Yayınları.

Laclau, E. ve Mouffe, C. (2015). Hegemonya ve sosyalist strateji. (A. Kardam, Çev.). İletişim Yayınları.

Lievrouw, L. A. (2016). Alternatif ve aktivist yeni medya. (İ. S. Temizalp, Çev.). Kafka Yayınları.

Lovink, G., and Rossiter N. (2005). Dawn of the organised networks. The Fibreculture Journal.5. http://five.fibreculturejournal.org/fcj-029-dawn-of-the-organised-networks/

Medosh, A. (2016). Shockwaves in the new world order of information and communication. Christiane Paul, Hoboken. (Ed.). A Companion to Digital Art içinde (s. 355-383).John Wiley and Sons Inc.

Mouffe, C. (2015). Dünyayı politik düşünmek agonistik siyaset. (M. Bozluolcay, Çev.). İletişim Yayınları.

Raley, R. (2009). Tactical media. Minneapolis. University of Minnesota Press.

Ransome, P. (2010). Antonio Gramsci - yeni bir giriş. (A.İ. Başgül, Çev.). Dipnot Yayınları.

Scholl, C. (2015). Bakunin'in zavallı kuzenleri: sanat yoluyla taktiksel müdahale. (B. Taș. Çev.). B. Ö. Fırat ve A. Kuryel (Ed.). Küresel ayaklanmalar çağında direniş ve estetik içinde (s. 197-225) İletişim Yayınları.

Sennett, R. (2012). Beraber. (İ. Özkürapli, Çev.). Ayrıntı Yayınları.

Thompson, N. (2018). Íktidarı görmek 21. yüzyılda sanat ve aktivizm. (E. Kosova, Çev.). Koç Üniversitesi Yayınları.

Vila N. and Expósito M. (2007). https://archive.org/details/tacticalfrivolity

Wilson, P. L. (Hakim Bey). (2009). T.A.Z. geçici otonom bölge, ontolojik anarşi, şiirsel terörizm. (İ. M. Aru, Çev.). Altıkırkbeș Yayınları. 